\title{
Dislocation and backgrounding*
}

\author{
Mark de Vries \\ University of Groningen
}

\section{Introduction}

Dutch uses a variety of strategies to dislocate (or seemingly dislocate) elements from the main proposition. Next to potentially sentence-internal dislocations such as appositions and parentheses, the following types of peripheral dislocation exist: contrastive left-dislocation (CLD), hanging topic left-dislocation (HTLD), backgrounding right-dislocation (BRD), and afterthoughts (AFT); these are illustrated in $(1):^{1}$

(1) a. Die man, die mag ik niet.

that man DEM like I not

'That man I don't like.'

b. Die man, ik mag 'm niet.

that man I like him not

'That man, I don't like him.'

c. Ik mag 'm niet, die man.

I like him not that man

'I don't like him, that man.'

d. Mijn buurman kwam langs, Joop.

'My neighbor came along, Joop.'

There is a difference in intonation between (1c) and (1d): a backgrounded rightdislocated constituent is deaccented, whereas an afterthought, like many parentheticals, receives an additional intonation contour containing a pitch accent. Furthermore, the left-dislocated constituent in HTLD ( $1 \mathrm{~b}$ ) is followed by a pause, but this is usually not the case in CLD (1a).

As for the information structure, AFT provides new information (again, as in parentheses), but HTLD and BRD do not; CLD may but need not provide new information. Furthermore, HTLD is the only construction in which the relevant constituent is necessarily a pragmatic aboutness topic (in the sense of Reinhart 1982).

In this paper I will compare the constructions in (1) from a syntactic point of 
view, and propose a general approach to dislocation in terms of specifying coordination. In some more detail I will argue that CLD is not dislocation at the clause level: the leftmost phrase is a major constituent of the clause, and the demonstrative is appositively construed with respect to it.

\section{Categorial possibilities}

CLD can be used with practically all categories and syntactic functions; this is illustrated in (2). ${ }^{2}$ In each case the distal demonstrative appropriate for the particular category and function is selected; this demonstrative (italicized) is obligatorily adjacent to the peripheral phrase.

(2) CLD

a. Joop, dat is de leukste jongen.

(DP, subject of small clause)

Joop that is the nicest boy

'Joop, he is the nicest boy.'

b. Een rotzak, dat is hij.

(DP, predicate)

a bastard that is he

'A bastard, that's what he is.'

c. Knap, dat is hij zeker.

handsome that is he certainly

(AP, predicate)

'Handsome, he certainly is.'

d. In de tuin, daar zaten ze.

in the garden there sat they

'In the garden is where they sat.'

e. Met een hamer, zo sloopt hij de stoel.

(PP, manner)

with a hammer so demolishes he the chair

'With a hammer is how he demolishes the chair.'

f. Tijdens de vergadering, toen brak de hel los.

(PP, time: past)

during the meeting then broke the hell loose

'It was during the meeting that all hell broke loose.'

g. Als Joop komt, dan vertrek ik.

( $\mathrm{CP}$, conditional clause)

if Joop comes then leave I

'If Joop comes, then I will leave.'

h. Dat hij zo laks is, dat ergert mij.

(CP, subject)

that he so sloppy is that annoys me

'That he is so sloppy, that's what annoys me.'

i. Een taart bakken, dat heeft hij nooit gekund.

(MiddlefieldP)

a cake bake that has he never been.able

'To bake a cake is what he has never been able to.' 
Every example in (2) can be changed into a construction involving 'normal' topicalization simply by leaving the demonstrative out; for example, $(2 \mathrm{c})$ and (2i) correspond to (3a) and (3b), respectively:

(3) a. Knap is hij zeker.

b. Een taart bakken heeft hij nooit gekund.

Thus, there seems to be a close relationship between topicalization and CLD in Dutch (more generally, V2-languages).

The state of affairs is quite different for HTLD. Acceptable examples always involve a nominal phrase; see (4) versus (5). The resumptive pronoun (italicized) is not in the CP domain. ${ }^{3}$

(4) HTLD

a. De kroonprins, ik heb 'm nog nooit in het echt gezien. (DP, object) the crown prince I have him yet never in the real seen 'The crown prince, I have never seen him in real life, yet'.

b. Dit boek, hij heeft er nog niet in gelezen. (DP, object of P) this book he has there not yet in read 'This book, he hasn't looked in it, yet.'

(5) a. ${ }^{*}$ In de tuin, Joop heeft er vanmiddag gezeten. in the garden Joop has there this.afternoon sat 'In the garden, Joop sat there this afternoon.'

b. ${ }^{\star}$ Met een hamer, hij sloopt $z o$ de stoel. with a hammer he demolishes so the chair 'With a hammer, he demolishes the chair that way'.

c. ${ }^{*}$ Knap, de prinses is 't helaas niet. pretty the princess is it unfortunately not 'Pretty, the princess is it not, unfortunately'.

d. * Dat hij onschuldig was, hij heeft ' $t$ nooit beweerd. that he innocent was he has it never claimed 'That he was innocent, he has never claimed it.'

The contrast between (4) and (5) is related to the fact that the hanging constituent in HTLD must be an aboutness topic, which is necessarily a nominal phrase. ${ }^{4}$

On the other hand, right-dislocation shows the complete range of possibilities attested in CLD as well. This is shown for BRD and AFT in (6) and (7), respectively (also recall (1c/d) for DPs).

(6) BRD

a. Ik ben er wel eens geweest, in Groningen.

I have there once been in Groningen

'I have been there once, in Groningen.' 
b. Je weet nooit of je 't nog eens wordt, depressief. you know never if you it yet once becomes depressed 'You never know if you will get it some day, depressed.'

c. Ik heb 't me inderdaad afgevraagd, of de baas ook komt.

I have it me indeed wondered if the boss also comes

'I have indeed wondered it, whether the boss will also come.'

d. Ik heb 't nooit gekund, een omelet bakken.

(MiddlefieldP)

I have it never been.able an omelette fry

'I have never been able to do it, make an omelette.'

(7) AFT

a. Mijn buurvrouw kwam langs, gekleed in een baljurk.

my neighbor:FEM came along dressed in a ball.gown

'My neighbor came along, dressed in a ball gown.'

b. De rozen bloeien nog — in de winter!

the roses flower still in the winter

'The roses still flower - in winter!'

c. De boekenkast viel om - wat een toestand was dat.

the bookcase fell over what a situation was that

'The bookcase fell over - what a mess.'

The examples in (7) raise the question what the difference is between (i) afterthoughts, (ii) right-peripheral parentheticals, and (iii) extraposed parenthetical phrases or clauses (for instance, appositions or non-restrictive relative clauses). My answer is simply that there is none.

To be sure, cases like (7) must be distinguished from restrictive right-peripheral material (such as extraposed restrictive relative clauses and prepositional phrases, $\mathrm{PP}$-over-V, and object sentences), which is included in the intonation contour of the (matrix) context and often carries the main sentence stress. Dutch sentence structure, then, schematically looks as in (8):

(8) LD - prefield - V2 - middle field - V-final - postfield - RD

Topicalized constituents are in the prefield; extraposed ones in the postfield. The regular clause structure ranges from the prefield to the postfield. Actually dislocated constituents can be regarded as leftward and rightward parentheses.

Can it be shown that the constructions other than AFT also involve actual dislocation? The next section investigates this question on the basis of connectivity effects. 


\section{Connectivity effects}

In CLD, HTLD, and BRD constructions the peripheral constituent is represented by a pronoun in the matrix. One may wonder if there are reconstruction or matching effects. If so, this would be an argument against true dislocation. There is a clear consensus in the literature that indeed there are such effects in CLD, but not in HTLD. To this I may add that BRD is on a par with HTLD. I will illustrate briefly here, emphasizing the general pattern and ignoring complications for reasons of space. (As always with reconstruction data, the judgments can be a bit delicate.)

In CLD, but not HTLD, there is obligatory Case matching between the leftmost constituent (if it is a DP) and the preposed demonstrative. See, e.g., Van Riemsdijk (1997), Grohmann (2003), and Shaer \& Frey (2004) for illustrations and references concerning German and Icelandic. ${ }^{5}$ The following examples are taken from Van Haaften, Smits \& Vat (1983:135):

(9) Dessum hring, honum hefur Ólafur lofađ Maríu. this ring-DAT, it-DAT has Olaf promised Maria 'This ring, Olaf has promised to Maria.'

(10) Dessi hringur, Ólafur hefur lofađ Maríu honum. this ring-NOM, Olaf has promised Maria it-DAT 'This ring, Olaf has promised it to Maria.'

Returning to Dutch, examples concerning variable binding indicate that there is reconstruction in CLD (as in ordinary topicalization) but not in HTLD or BRD:

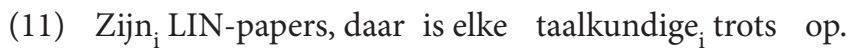

his LIN-papers there is every linguist proud of.

'His LIN papers, every linguist is proud of.'

(12) ${ }^{*} \mathrm{Zijn}_{\mathrm{i}}$ LIN-papers, elke taalkundige $e_{\mathrm{i}}$ is er trots op. his LIN-papers every linguist is there proud of. 'His LIN papers, every linguist is proud of them.'

(13) * Elke taalkundige ${ }_{i}$ is er trots op, zijn $_{\mathrm{i}}$ LIN-papers. every linguist is there proud of his LIN-papers. 'Every linguist is proud of them, his LIN papers.'

The pattern in (11)-(13) can be confirmed by anaphor binding:

(14) Pikante verhalen over zichzelf, die hoort Joop niet graag. juicy stories about SE-self those hears Joop not gladly 'Juicy stories about himself, Joop doesn't like to hear.' 
$(15){ }^{\star}$ Pikante verhalen over zichzelf $_{\mathrm{i}}$, Joop $\mathrm{p}_{\mathrm{i}}$ hoort ze niet graag.

(HTLD) juicy stories about SE-self Joop hears them not gladly 'Juicy stories about himself, Joop doesn't like to hear them.'

$(16){ }^{\star}{ }^{\text {Joop }}$ hoort ze niet graag, pikante verhalen over zichzelf $_{\mathrm{i}}$. Joop hears them not gladly juicy stories about SE-self 'Joop doesn't like to hear them, juicy stories about himself.'

The sentences in (15) and (16) become fine if we change zichzelf into hemzelf, which is not a local anaphor.

Furthermore, certain idiom chunks can be reconstructed in CLD, but not in HTLD or BRD (depending on a number of conditions such as relative transparency and the possibility of contrast); see (17)-(19). Here, krijg de klere means something like 'drop dead'; etymologically, klere is derived from the word 'cholera'.

(17) De klere, dat kan hij krijgen!

the $<$ id. $>$ that can he get

(18) ${ }^{\star}$ De klere, hij kan het krijgen. the $<$ id. $>$ he can it get

(19) ${ }^{\star}$ Hij kan het krijgen, de klere. he can it get the $<$ id. $>$

The reconstruction effects in CLD suggest that there is movement. If so, it would not be surprising if locality effects show up, contrary to the situation in HTLD and BRD. This is indeed the case, witness (20)-(22):

(20) * Madame Bovary, dat zou me zeer verbazen als hij gelezen had. Madame Bovary that would me very.much surprise if he read had 'Madame Bovary, it would surprise me very much if he had read.'

(CLD)

(21) Madame Bovary, het zou me zeer verbazen als hij 't gelezen had. Madame Bovary it would me very.much surprise if he it read had 'Madame Bovary, it would surprise me very much if he had read it.' (HTLD)

(22) Het zou me zeer verbazen als hij't gelezen had, Madame Bovary. it would me very.much surprise if he it read had Madame Bovary 'It would surprise me very much if he had read it, Madame Bovary.'

Here, (the base position of) the resumptive is inside an adjunct clause. See also Zwart (2001) concerning violations of the Right Roof Constraint in BRD. ${ }^{6}$

In short, CLD behaves differently from HTLD and BRD; this can be shown with a variety of reconstruction effects, such as Case matching, variable binding, anaphor binding, idiom interpretation, and locality. 


\section{Specification at different levels}

We established that there is no reconstruction, hence no movement, in HTLD and BRD constructions. This implies that these involve base-generated dislocation at the sentence level. What does this look like structurally? I propose to use the concept of specifying coordination, originally developed for appositions.

Koster (2000) and De Vries (2006) argue that coordination is a syntactic construction with a varying semantics depending on the particular coordinative head: e.g., and, or, but in English. Next to conjunction, disjunction, and opposition, there is also specification. Specifying coordination is represented as a 'colon phrase' :P, a special instance of CoP. A canonical :P is an appositional construction, for instance my neighbor, Ann, or something ugly: a pearl necklace. In each case, the apposition is a specification of the anchor. (The colon can be paraphrased by strings like namely, or, that is, indeed, I mean, as you know. ${ }^{7}$ )

I do not see any reason why the application of :P should be restricted to the constituent level. In fact, if we use it at the root level, we obtain a plausible representation of HTLD:

$$
[: \mathrm{DP}[: \mathrm{CP}]]
$$

Here, $\mathrm{CP}$ is a proposition providing more information on the topical, dislocated DP. This is specification at the sentence level. A paraphrase of the construction is the following: as for DP, <sentence $>$. Normally, the topic has a function within CP. ${ }^{8}$ As the clause must be syntactically complete, it cannot contain a gap, so there is a pronominal representation of the topic. The lack of a movement relation between DP and the CP-internal position straightforwardly explains the absence of reconstruction effects discussed in Section 3.

The colon phrase has a structurally distinguishable specifier and complement position, and therefore it is asymmetric (like any XP). In this case the asymmetry clearly reflects the information strcuture: an apposition specifies its anchor, a clause specifies a left-peripheral hanging topic, and not the other way around. Interestingly, the mirror image of HTLD exists in the form of right-dislocation (whether it concerns BRD or AFT). Its representation is shown in (24). Recall from Section 2 that right-dislocated constituents are not necessarily aboutness topics, and can be of any syntactic category XP.

$$
\text { [:P } \mathrm{CP}[: \mathrm{XP}]]
$$

$(\mathrm{BRD} / \mathrm{AFT})$

In this configuration, $\mathrm{CP}$ must be understood in the light of XP: XP adds information on $\mathrm{CP}$. If $\mathrm{CP}$ contains a cataphoric pronoun (as is usually the case in $\mathrm{BRD}$ ), $\mathrm{XP}$ relates to this pronoun more specifically; this, however, cannot be a direct syntactic relationship, as was shown in Section 3, so it must be a pragmatic inference. Again, since there is no movement involved, no connectivity effects are expected. 
In (24) XP specifies CP; it does not directly interfere with its compositional semantics. This is similar to situations involving parenthesis, apposition, nonrestrictive relativization, or subsequent sentences. In De Vries (2007) I argue that parentheses and appositions involve a special type of Merge, related to the use of the colon phrase; this b-Merge creates a 'nonsubordinative hierarchy', and blocks c-command relations and movement (for reasons of space I cannot go into this, here). ${ }^{9}$ On the semantic side, we can attribute the effect just described to it (namely, the start of an independent proposition); on the phonological side, it may have the effect of starting a new intonation contour (possibly interrupting the contour of the host clause). Thus, we can make a nice generalization in extending the use of specifying coordination to peripheral dislocation.

Now, let us turn to CLD. The data in the previous section indicate that the leftmost constituent in CLD is actually part of the clause, i.e. not dislocated at all. Therefore, suppose that this constituent is generated inside the clause, and subsequently moved to the left periphery. This basic idea was proposed first, I think, in Van Haaften, Smits \& Vat (1983). They argue that the relevant XP and the demonstrative pronoun are generated together in the clause-internal base position, and Vergnaud-raised to the ComP domain; subsequently, XP is moved out of what we might call the 'big XP', and left-dislocated to the sentence.

There are a number of objections to this approach: it is unclear what licenses the additional dislocating movement, it is unclear what the internal structure of the big XP looks like, it is unclear what the function of the pronoun is, and it is unclear why there is Case matching between the pronoun and the XP (if it involves a DP). ${ }^{10}$ Nevertheless, the idea of A'-movement is a solution for the reconstruction effects discussed above. Let us simply discard the additional movement, and assume that the dislocation is only apparent. This gives us the following:

$$
\left[_{\mathrm{CP}}[\mathrm{XP} \text { Dem }]_{\mathrm{i}} \mathrm{V} 2 \ldots \mathrm{t}_{\mathrm{i}} \ldots\right]
$$

The parallels between topicalization and CLD fall out from such an analysis immediately.

Next, consider the question of the internal makeup of [XP Dem]. In case XP is a nominal phrase, there are two determiners (e.g., die man die 'that man DEM'). It might be tempting to try Kayne's (1994) solution to relative clauses, which consists of externalizing the determiner belonging to NP, and reanalyzing the (relative) pronoun as a determiner of NP in its base position:

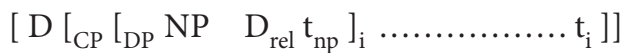

$$
\begin{aligned}
& \text { a. de man die ik bewonder (relative construction) } \\
& \text { the man whom I admire } \\
& \text { b. Die man die bewonder ik. } \\
& \text { that man DEM admire I }
\end{aligned}
$$


However, this is out of the question for a number of reasons. First of all, the first determiner in a CLD construction does not take scope over the clause, and the clause is not a subordinate clause. Secondly, CLD is possible with categories other than DP, and the second D cannot be construed with, say, a preposition. (For a similar argumentation against applying a pure Kaynian model to appositive relative clauses, see De Vries 2006.) There is, however, a completely different alternative (again, with some similarities - this time positive - to De Vries's 2006 approach to appositive relatives). Suppose it is not XP that is dislocated (as discussed), but rather the demonstrative pronoun, namely on the constituent level; the demonstrative, then, is attached as an apposition to XP. The analysis for CLD, then, is schematically provided in (27):

$$
\left[_{\mathrm{CP}}[: \mathrm{XP}[: \mathrm{Dem}]]_{\mathrm{i}} \mathrm{V} 2 \ldots \mathrm{t}_{\mathrm{i}} \ldots\right]
$$

The proposal in (27) straightforwardly explains most properties of CLD: the similarities with topicalization (in particular reconstruction effects and A'-movement), the adjacency between XP and the demonstrative, the apparent V3 order, the obligatory agreement in Case, phi-features and syntactic function between XP and Dem, the locality effect, and potential intonational effects (since an apposition is paratactic). With respect to Case agreement, note that an ordinary apposition usually gets the same Case as the anchor. This is illustrated in Czech in (28) (Radek Šimík, p.c.). (Similar examples can be construed in German.)

(28) Viděl jsem Richard-a, mé-ho soused-a.

(Czech) see AUX:PAST:1sG Richard-ACC my-ACC neighbor-ACC

'I saw Richard, my neighbor.'

As noted, XP in (27) is not necessarily a DP. This means that the appositional structure can be syntactically unbalanced. However, it is well-known that coordination can be unbalanced as long as the conjuncts are functionally equivalent. The same is true for appositions in general (see, e.g., Heringa \& De Vries to appear). Moreover, since (27) involves a pronoun, and pronouns can be associated with any syntactic category, we predict that it is easy to construe 'unbalanced' CLD, which is consistent with the facts in (2).

It is, however, not evident that a pronoun can function as an apposition to begin with. Normally, an ordinary personal pronoun would add no information to an R-expression; hence, we would create a vacuous specification. It is no coincidence, I believe, that the pronoun in a CLD construction is a demonstrative. A demonstrative does add information: deixis (an explicit discourse link) and explicit contrast. This is exactly what is needed in CLD. A paraphrase of the idea is $X P$, namely that person/thing/... (and nothing else). 
The proposed way of construal is reminiscent of the pronominal summary strategy of coordination, used in, e.g., Baram Kayan (spoken in Malaysia), Mapudungun (Chile), Baoulé (Côte d'Ivoire), and Amele (Papua New Guinea); see Zwart (2005) and Haspelmath (2007) for a general description and further references. An example from Amele is cited from Roberts (1987:103) in (29), where I have italicized the summary element:

(29) Tupau Wawac Kuma age me bile-ig-a fo?

Tupau Wawac Kuma 3PL good be-3PL-TODAY.PAST Q

'Are Tupau, Wawac, and Kuma well?'

To me, this strategy only makes sense if it can be analyzed (pretheoretically) such that the summary pronoun is attached as an apposition to the ensemble of juxtaposed (or even overtly coordinated) (noun) phrases. Schematically: [[X(P), Y(P), ...] : (i.e.) those/they]. (In Dutch we can also say mijn boeken, platen en CD's, al die dingen / dat alles 'my books, records, and CDs, all those things / all that'.) Of course the function of summary coordination is different from CLD, but it seems to support the idea that, depending on the function of a particular construction, it could be meaningful to use a pronoun as an apposition, and that this possibility is allowed by the grammar in general. ${ }^{11}$

\section{Conclusion}

Dislocation is parenthetic construal; it can operate at different levels and in different ways. In Dutch, we can distinguish hanging topic left-dislocation, contrastive left-dislocation, backgrounding right-dislocation, afterthoughts, and sentenceinternal parenthesis (including parentheticals and appositions). The dislocated constituent in a HTLD construction is a pragmatic aboutness topic, and hence a nominal phrase; the other types are categorially free. The leftmost constituent in a CLD construction is only apparently dislocated; a variety of reconstruction effects (variable and anaphor binding, idiom interpretation, Case matching, locality) show that it is actually part of the clause, and A'-moved to the left periphery. Rather, I argued, it is the demonstrative pronoun that is dislocated at the constituent level, namely as an apposition to the leftmost phrase. By contrast, the topic in a HTLD construction is base-generated at the sentence level; for this, we can use a similar kind of specifying projection. Right-dislocation is the structural mirror image of HTLD, which mimics the information structure: in a HTLD construction, the sentence adds information to the topic; in a right-dislocation construction, the dislocated phrase specifies the preceding sentence. If we use BRD, this phrase is a reminder of information that is in fact old; if we use an afterthought, it 
contains new information. An afterthought, therefore, is an ordinary parenthetical: it contains side-information (which may relate to the sentence as a whole, or a part of it), and it has an independent intonation contour.

\section{Notes}

* I thank the audiences of TIN-2007, 'What's the topic?' (Nijmegen, 23-1-2007), and the Groningen syntax seminar (Jan./Feb. 2007), as well as the anonymous LIN-reviewer for their comments and questions. This research was financially supported by the Netherlands Organisation for Scientific Research (NWO).

1. CLD is in some ways comparable to (but certainly not equal to) clitic left dislocation (CLLD) as attested in Italian and Greek, for instance. As for HTLD, Jansen (1981) warns that it is extremely rare in corpora of spoken Dutch. Nevertheless, since he puts some effort in describing its properties, I take it that he does not question the status of HTLD as an acceptable construction of Dutch.

2. Prepositional objects seem to be an exception: ?* Over computers, daar(over) sprak hij (over) [about computers, there(about) spoke he (about)]; ?* Aan haar fiets, daar(aan) dacht ze (aan) [of her bike, there(of) thought she (of)]. If, however, only the nominal phrase contained in the PP is contrastively dislocated, the sentences become perfect: Computers, daar sprak hij over [computers, there spoke he about] 'Computers, that's what he spoke about'; Haar fiets, daar dacht ze aan [her bike, there thought she of] 'Here bike, that's what she thought of'.

3. In (4b) er...in 'there...in' is the result of an R-transformation (in het 'in it' $\rightarrow$ erin 'therein'), followed by movement of the pronoun.

4. The latter is confirmed for shifting aboutness topics in German by Frascarelli \& Hinterhölzl (2007). In Italian, however, it seems that at least PPs with an indirect object role may constitute an shifting topic, albeit in clitic left-dislocation (CLLD) constructions only. The relevant example is Credo che domani, a Gianni, questo gli dovremmo dire 'I think that tomorrow, to Gianni we should tell him this'. (Notice that in general, aboutness topics can be shifting/new or continuing. Furthermore, it should be clear that regular (nonhanging) topics can be [+aboutness], too.)

5. To the extent that pronouns can figure in CLD, there is a clear Case connectivity effect in Dutch as well: Hem/*hij die mag ik niet [him/he DEM like I not] 'Him/*he, I don't like'. For HTLD the judgments are unclear.

6. Zwart also shows that a right-dislocated constituent is not interpreted as having narrow scope with respect to the clause. However, it is easy to show that it also does not have wide scope in terms of c-command (e.g., binding of a clause-internal variable by the RD phrase is impossible). The conclusion must be that the clause and the RD phrase are not in each other's c-command domain (see De Vries, 2007, for suggestions how such a result can be obtained in parenthetic construal in general). The 'wide interpretation effect' that Zwart observed, then, is similar to the pragmatic interaction between independent sentences. 
7. In some cases there can be an overt apposition marker (see especially Heringa \& De Vries, to appear). If the marker is a head (or, for instance), it can simply be put in the coordinator position; however, phrasal markers raise the question what their structural position is. Two different approaches are suggested in De Vries (2002) and Heringa (2006), respectively; but clearly more research is needed on the subject.

8. Loose Aboutness Left Dislocation (where DP is not represented in CP) is classified as a separate type in Van Riemsdijk (1997). An illustration in French is Oh, tu sais, moi, la bicyclette, je n'aime pas me fatiguer [oh, you know, me, the bicycle, I don't like to tire myself] (taken over from Van Riemsdijk 1997:4). Here, the relevant element is bicyclette 'bicycle'. In Germanic this construction is unacceptable.

9. Parenthesis is different from apposition and the other types of dislocation in that there is no anchor. In De Vries (2007) I argue that a parenthetical XP is in an adjoined position (like an adverbial phrase), but embedded in a (monovalent) specifying phrase (making use of b-Merge).

10. Namely, in Vergnaud-raising applied to relative clauses, it is essential that the relative pronoun and the antecedent to which is initially attached may bear different Cases: the relativeinternal Case for the pronoun, and the Case provided by the matrix for the antecedent.

11. An interesting example is the following: Anna's broer, die 'Anna's brother, that one' - where die [DEM] is deictic and focused, presupposing that Anna has more than one brother - can be used in a CLD construction yielding Anna's broer, die, die heeft een hond 'Anna's brother, that one, DEM has a dog.' Here, the first die is disambiguating, and the second die is contrastive with respect to the predicate heeft een hond. Obviously, the complex Anna's broer, die, die cannot be used in isolation, since the function of the second die is related to the topic position.

\section{References}

Frascarelli, Mara \& Roland Hinterhölzl. 2007. “Types of Topics in German and Italian”. On Information Structure, Meaning and Form ed. by Susanne Winkler \& Kerstin Schwabe, 87-116. Amsterdam: John Benjamins.

Grohmann, Kleanthes. 2003. Prolific Domains. Amsterdam: John Benjamins.

Haaften, Ton van, Rik Smits \& Jan Vat. 1983. "Left dislocation, connectedness, and reconstruction". On the formal syntax of the Westgermania ed. by Werner Abraham, 133-154. Amsterdam: John Benjamins.

Haspelmath, Martin. 2007. "Coordination". Language typology and linguistic description, 2nd edition ed. by Timothy Shopen. Cambridge: Cambridge University Press.

Heringa, Herman. 2006. The structure of appositional constructions. Ms, University of Groningen. <http://www.let.rug.nl/ heringa/1styear_report.pdf> (11 June 2007)

Heringa, Herman \& Mark de Vries. To appear. "Een semantische classificatie van apposities". Nederlandse Taalkunde 12.

Jansen, Frank. 1981. Syntactische konstrukties in gesproken taal. Amsterdam: Huis aan de drie grachten.

Kayne, Richard. 1994. The Antisymmetry of Syntax. Cambridge, Mass.: MIT Press. 
Koster, Jan. 2000. Extraposition as parallel construal. Manuscript, University of Groningen. $<$ http://odur.let.rug.nl/ koster/papers/parallel.pdf> (11 June 2007)

Reinhart, Tanya. 1982. Pragmatics and linguistics: An analysis of sentence topics. Bloomington, Indiana: Indiana University Linguistics Club.

Riemsdijk, Henk van. 1997. "Left Dislocation". Materials on Left Dislocation ed. by E. Anagnostopoulou, H. van Riemsdijk \& F. Zwart, 1-10. Amsterdam: John Benjamins.

Roberts, John R. 1987. Amele. London: Croom Helm.

Shaer, Benjamin \& Werner Frey. 2004: “'Integrated' and 'Non-Integrated' Left-peripheral Elements in German and English". Proceedings of the Dislocated Elements Workshop, ZAS Berlin, November 2003 (ZAS Papers in Linguistics 35) ed. by Benjamin Shaer, Werner Frey \& Claudia Maienborn, 465-502. Berlin, ZAS.

de Vries, Mark. 2002. "Coördinatie in drie dimensies". TABU 32.62-73.

de Vries, Mark. 2006. “The Syntax of Appositive Relativization. On Specifying Coordination, False Free Relatives and Promotion". Linguistic Inquiry 37.229-270.

de Vries, Mark. 2007. "Invisible Constituents? Parentheses as B-Merged Adverbial Phrases". Parentheticals ed. by N. Dehé \& Y. Kavalova, 203-234. Amsterdam: John Benjamins.

Zwart, Jan-Wouter. 2001. Backgrounding ('right dislocation') in Dutch. Ms, University of Groningen. <http://www.let.rug.nl/ Zwart/docs/backgr.pdf> (11 June 2007)

Zwart, Jan-Wouter. 2005. "Some notes on coordination in head-final languages". Linguistics in the Netherlands 22.231-242. 